\title{
The Development of Learning Media Based On Visual Using Snake and Ladder Board Games to the Learning Outcomes of Early Age Children in TK Karya Darma Medan
}

\author{
Andrew Ryan Hasudungan Siallagan ${ }^{1}$, Julaga Situmorang ${ }^{2}$, Harun Sitompul $^{3}$ \\ \{andrewsiallagan054@gmail.com ${ }^{1}$ \}
}

\begin{abstract}
Postgraduate Programe Universitas Negeri Medan, Indonesia ${ }^{1}$, Jurusan Pendidikan Teknik Mesin Universitas Negeri Medan, Indonesia ${ }^{2}$, Jurusan Pendidikan Teknik Bangunan Universitas Negeri Medan, Indonesia ${ }^{3}$
\end{abstract}

\begin{abstract}
This study aims to: produce visual based learning media product that are feasible to use, easily learned by students and can be used for early of childhood. This type of research is developing the Borg and Gall product development model of Dick and Carey's learning design model. The result of the study showed: (1) the expert test was very good qualification $(93,13 \%)$, (2) the learning design expert qualifications were very good ( $93,13 \%)$, (3) the test media learning expert qualifications were very good (93,75\%), (4) individual qualification trials are very good $(95,16 \%)$, (5) small group trials of very good qualifications $(96,01 \%)$, (6) field trials are limited to very good qualifications $(96,12 \%)$, and is suitable for use in the process of learning early of childhood. The result of hypothesis testing prove that there are significant differences between student learning outcomes learned by using media products with student learning outcomes learned without using media product. This is indicated by the results of data processing obtained by $\mathrm{t}$-count $=$ $4,782>\mathrm{t}$ table $=1,679$, with $\mathrm{dk}=9$ at the significance level $\alpha=0.05$. It was concluded that the group learning outcomes of students who were taught using visual based learning media product using snake and ladder board games were $82,3 \%$ higher than the group of students who were taught without learning media product of 80,0 .
\end{abstract}

Keywords: Games Learning, Visual Learning Media, Games Education

\section{Introduction}

Early childhood brain development is greater at 0 to 8 years in the future and the remaining $20 \%$ is determined for the remainder of his life after childhood, and of course the form of stimulation provided must be in an appropriate manner in accordance with the level of early childhood development. Observing the development that occurs in children is a fun activity where at that time the child's development is very fast. These developments include physical, cognitive and social emotional development.

The meaning of play which is a fun activity carried out for the benefit of the activity itself. Playing is an activity that helps children to achieve complete development both physically, mentally and emotionally [1]. In carrying out children's play activities require play equipment. 
Based on the results of researchers' interviews with the teacher's board at TK Karya Darma, that, their children's cognitive abilities are still lacking especially in terms of mentioning numbers 1-10, children are still stammering and need help from teachers to mention numbers 110. The snakes and ladders game tool already exists but its use is just a toy played by children not to be used as a method in cognitive learning.

Based on the results of researchers' survey in TK Karya Darma, it is known that the problem is that teachers lack a maximum role in developing the cognitive aspects of children through the play process. The learning process is set up with classical learning patterns, where the teacher stands in front of explaining the material and students (students) are asked to sit listening and the learning patterns as above are very monotonous because the interaction only takes place in one direction, namely from teacher to students, less interactive between teachers and students, or between students with other students. Ideally, the teacher in giving lessons should be interspersed with various games. Because learning while playing will be an important vehicle for children to develop all their potential including cognitive aspects.

Based on observations carried out, the researchers will conduct research on the development of an integrated snake ladder media in TK Karya Darma. Researchers chose the snake ladder game media because TK Karya Darma did not use the media, but only used printed books. This game is an interesting medium for students so that they can motivate students to learn. In addition, the snake ladder game media has never been used as a learning medium.

This study aims to develop visual-based ladder snake game media for early childhood that is feasible and effective. This is intended so that students can understand the concept of learning material through the media contained in the snake and ladder game. Snakes and ladders game media will be developed in an integrated manner so that it is attractive to students.

Snakes and ladders game is interactive, educational and entertaining, simple and practical. This makes the snakes and ladders game favored by children, because of its simple and interesting nature. This is expected to arouse children's interest in traditional games and develop interesting and innovative media as play media and as a learning tool.

\section{Research Method}

The method used in this research is Borg and Gall development research. The subject in this study was the material "Lingkunganku" contained in the RPPM (Weekly Learning Program Plan). The object in this study is TK Karya Darma Medan students who are studying "Lingkunganku" learning material. Data obtained by giving questionnaires and objective tests of learning outcomes. The data obtained were then tested for normality and homogeneity. The hypothesis of this study will be tested using the analysis of the T-test (t-test).

\section{Results and Discussion}

The data obtained in this study are the results of assessments by material experts, instructional design experts and instructional media experts and early childhood learning outcomes of TK Karya Darma. Based on the results of the assessment of learning material experts assess that visual-based learning media using the snake ladder game in learning " Lingkunganku" developed environment has had feasibility on three aspects of assessment which include aspects of content worthiness with a percentage score of $94.27 \%$ and the feasibility 
aspect of the presentation of $91.67 \%$. This indicates that the interactive learning media developed can meet the demands of learning needs. The percentage of assessment scores from the two material experts on visual-based learning media using the snakes and ladders game in "Lingkunganku" learning is shown in Table 1.

Table 1. Percentage of Results of Expert Material Assessment of Visual Based Learning Media Using Snakes and Ladders Games

\begin{tabular}{|c|c|c|}
\hline Indicator & Rating Percentage & Criteria \\
\hline Content Worthiness Aspect & 94.27 & Very feasible \\
\hline $\begin{array}{l}\text { Aspect of Presentation } \\
\text { Eligibility }\end{array}$ & 91.67 & Very feasible \\
\hline Total & 93.13 & Very feasible \\
\hline
\end{tabular}

Furthermore, the results of the design expert's assessment of the visual-based learning media using the snake and ladder game in "Lingkunganku" learning are shown in Table 2.

Table 2. Percentage of Results of Design Expert Assessment of Visual Based Learning Media Using Snakes and Ladders Games

\begin{tabular}{lcc}
\hline Indicator & Rating Percentage & Criteria \\
\hline Aspect of Appropriate Design Format & 93.75 & Very feasible \\
Aspects of Conformity of Learning & 93.75 & Very feasible \\
$\begin{array}{l}\text { Activity Order } \\
\text { Aspects of Conformity of Methods and }\end{array}$ & 93.75 & Very feasible \\
$\begin{array}{l}\text { Media in Learning Activities } \\
\text { Aspect of Appropriateness of Time }\end{array}$ & 87.5 & Very feasible \\
$\begin{array}{l}\text { Allocation } \\
\text { Design Physical Attractiveness Design }\end{array}$ & 92.5 & Very feasible \\
\hline$\quad$ Total & 93.13 & Very feasible \\
\hline
\end{tabular}

Furthermore, according to learning media experts, the development of visual-based learning media uses the snake ladder game in learning "Lingkunganku" has the feasibility of two aspects of assessment in terms of media construction which includes aspects of media design with a percentage score of $94.44 \%$ and aspects of media content design with a percentage score of $93.42 \%$. This indicates that the interactive learning media developed can meet the demands of learning needs. The percentage of assessment scores from the two design experts on visual-based learning media using the snakes and ladders game in "Lingkunganku" learning is shown in Table 3.

Table 3. Percentage of results of Media Expert Assessment of Visual Based Learning Media Using Ladder Snake Games

\begin{tabular}{ccc}
\hline Indicator & Rating Percentage & Criteria \\
\hline Media Design Aspects & 94.44 & Very feasible \\
Design Aspects of Media Content & 93.42 & Very feasible \\
\hline \multicolumn{1}{c}{ Total } & 93.75 & Very feasible \\
\hline
\end{tabular}

Furthermore, the data obtained in this study are the results of early childhood learning in TK Karya Darma Medan with "Lingkunganku" material. Based on the results of the study it can 
be seen that the minimum, maximum, mean and standard learning outcomes of early childhood in the media development group at TK Karya Darma Medan can be seen in Table 4.

Table 4. Minimum Learning Results, Maximum, Mean and Standard Deviation in Early Childhood in the Intervention Group at TK Karya Darma Medan

\begin{tabular}{lcccc}
\hline Learning Outcomes & Min. & Max. & Mean & Std. Deviation \\
\hline Pre Media Development & 60 & 90 & 77.5 & 4.553 \\
Post Media Development & 77.5 & 100 & 88.75 & 2.714 \\
\hline
\end{tabular}

Based on Table 4, it can be seen that the learning outcomes in early childhood TK Karya Darma Medan in the intervention group minimum learning outcomes after given the development of learning media has increased from 60 to 77.5, the maximum learning outcomes after the intervention in the development of learning media has increased from 90 to 100 and the mean (average) of learning outcomes after being given the development of instructional media has increased from 77.5 to 88.75 after the experiment.

The learning outcomes data are then subjected to an analysis prerequisite test which includes a normality test and a homogeneity test. Normality test conducted on learning outcomes data in this study is the Liliefors test. Normality of data is significant if the test results $l>0.05$. The results of the normality of pretest and posttest data can be seen in Table 5 .

Table 5. Data Normality Test for Experiment Class and Control Class

\begin{tabular}{lccc}
\hline Data & Class & $\boldsymbol{l}$-count & l-table \\
\hline Pretest & Experiment & 0.197 & 1.796 \\
Posttest & Experiment & 0.126 & 1.833 \\
Pretest & Control & 0.137 & 1.833 \\
Posttest & Control & 0.137 & 1.833 \\
\hline
\end{tabular}

Based on the results of normality testing in the experimental class and the control class in Table 5 , it is known that the pretest and posttest data in both classes produce a normality test value $(l)>0.05$. Thus, it can be concluded that learning outcomes data in the experimental class and the control class are normally distributed. Homogeneity test conducted in this study uses the Lavene Equality of Error Variances Test. Homogeneity of data is fulfilled if the significance test results obtained $>0.05$. Homogeneity test results of pretest and posttest data can be seen in Table 6.

Table 6. Test Homogeneity of Pretest and Posttest Data

\begin{tabular}{lccc}
\hline Data & Class & p-value & A \\
\hline Pretest & $\begin{array}{c}\text { experiment } \\
\text { control } \\
\text { Posttest }\end{array}$ & 3,034 & 1,685 \\
& $\begin{array}{c}\text { experiment } \\
\text { control }\end{array}$ & 0,025 & 1,685 \\
\hline
\end{tabular}

Based on the results of homogeneity testing in the experimental and control classes in Table 6, the results of the pretest and posttest significance obtained $>0.05$. Thus, it can be 
concluded that the pretest and posttest learning outcome data in the experimental class and the control class are homogeneous.

After the analysis prerequisite tests are met then the learning outcomes data are analyzed to test the research hypotheses. Hypothesis testing is done by the $t$ test formula. Based on the calculation results obtained by $\mathrm{t}$-count $<\mathrm{t}$-table $=1.679$. Based on these results, then Ho and ha are accepted or in other words there are significant differences between learning outcomes in the experimental class and the control class at the 5\% significance level. Thus, the results of "Lingkunganku" learning taught by the development of visual media based on the use of snakes and ladders have differences with the results of learning being tested.

To test the development of visual based learning media using the ladder snake game it is found that the results of the statistical test T-test obtained the value of $t$-count (4.782) $>\mathrm{t}$-table (1.679), meaning Ho is rejected, meaning that the development of visual based learning media using the ladder snake game is effective to improve learning outcomes early childhood in TK Karya Darma Medan.

\subsection{Discussion of Product Development Results}

Development of visual based learning media using ladder snake game based on the stages as contained in the procedure. The results of the subsequent development are carried out due diligence or validation by experts who have been determined. Based on the results of the validation carried out, the product in the form of a visual snake ladder game in learning "Lingkunganku" was declared very feasible to be continued in field trials. The learning media developed have met the standards based on the design of learning media development standards and learning material standards.

The product development research conducted was directed to produce a product in the form of visual-based learning media using the snakes and ladders game in learning "Lingkunganku" in early childhood TK Karya Darma which is used to improve early childhood learning outcomes. Aspects that are revised and refined based on data analysis and tested and input from material experts, learning design experts, learning media experts. It aims to explore some aspects that are common in the process of developing a product.

The results of the assessment presented by the material experts on the development of visual based learning media using the snake ladder game in learning "Lingkunganku" gives an average percentage of $93.13 \%$, thus the learning media are included in the category of "very feasible" so that it can be accepted and suitable for use in learning process. The results of the assessment of learning design experts in the development of visual-based learning media using the ladder snake game gives an average percentage score of $93.13 \%$ and meet learning design standards. Meanwhile, instructional media experts on learning media were phased in the development of visual based learning media using the snakes and ladders game, giving an average percentage of $93.75 \%$, thus the development of visual based learning media using the snakes and ladders game in learning "Lingkunganku" is included in the category of "very feasible "so that it can be accepted and is suitable for use because it contains material and delivery criteria that meet the delivery requirements of the message.

From the discussion above it can be concluded that the development of visual based learning media using the snake ladder game in learning "Lingkunganku" is appropriate for learning as learning media in TK Karya Darma Medan.

\subsection{Discussion of Research Results of Product Effectiveness Test}


Based on statistical tests that have been done, the results of hypothesis test analysis are obtained, namely $\mathrm{t}$-count $=4.782$ and $\mathrm{t}$-table $=1.679$ which is $\mathrm{t}$-count $>\mathrm{t}$-table, this means the use of visual based learning media using the snakes and ladders game can improve early learning outcomes on the subject of Lingkunganku in TK Karya Darma Medan, with an influence on improving learning outcomes by $50.97 \%$.

Snakes and ladders game can improve early learning outcomes because in this game early childhood are required to be quick and alert in answering questions when getting question cards and practice cards. Groups will compete to quickly answer the questions obtained and collect as many point cards as possible to be a winner. One of the essential characteristics of an individual is that he always wants to win in various ways [2]. Each individual will make various efforts so that he can be superior to others. His efforts can be in the form of positive and negative things.

The use of snakes and ladders game media can improve student achievement on the subject of hydrocarbons in TK Gracia Kids classrooms and the effect of increased use of snakes and ladders playing media on student achievement by $16.84 \%$ [3].

\section{Conclusions}

Based on the results of research that has been done and the results of data analysis obtained can be concluded as follows. Based on statistical tests that have been done, the results of hypothesis test analysis are obtained, namely $\mathrm{t}$-count $=4.782$ and $\mathrm{t}$-table $=1.679$ which is $\mathrm{t}$ count $>$ t-table, this means the use of visual based learning media using the snakes and ladders game can improve early learning outcomes on the subject of Lingkunganku in TK Karya Darma Medan, with an influence on improving learning outcomes by $50.97 \%$.

The results showed that the development of snakes and ladders game media had a positive effect in creating an active and enjoyable learning process. The development of visual snake ladder game media is proven to make students more enthusiastic and responsible for more active learning, which in turn has an impact on student learning outcomes better than without using media. Therefore, the development of a visual-based ladder snake game can be recommended for use in the early childhood learning process. Suggestions that can be given to teachers, to be able to implement this snake ladder game by planning learning better, so that the results obtained are more maximum and efficient.

\section{References}

[1] Munandar, S.C. Utami. Pengembangan Kreativitas Anak Berbakat. Rineka Cipta. Jakarta (2012).

[2] Nana Sudjana dan Ahmad Rivai. Media Pengajaran. Sinar Baru Algensindo. Bandung (2007).

[3] Rahmadani Sahri. Penggunaan Media Permainan Ular Tangga Untuk Meningkatkan Prestasi Belajar Siswa Pada Pokok Bahasan Hidrokarbon Di Kelas Xi Sma As-Shofa Pekanbaru. Program Studi Pendidikan Kimia Fakultas Keguruan dan Ilmu Pendidikan Universitas Riau (2015).

[4] Santrock, John W. Life-span Development : Perkembangan Masa Hidup. $5^{\text {th }}$ Edition, Jakarta : Erlangga (2002). 